JoAnNa NakonieCZny

Politechnika Rzeszowska, Polska - Rzeszów University of Technology, Poland

Renata Nesterowicz

Uniwersytet Rzeszowski, Polska - University of Rzeszów, Poland

\title{
Ocena systemu podatkowego w opinii przedsiębiorców z województwa podkarpackiego
}

\section{Evaluation of tax system by the entrepreneurs from the Podkarpackie Voivodeship (Poland)}

\begin{abstract}
Streszczenie: Polska jest krajem o najbardziej zmiennym i nieprzewidywalnym prawie ze wszystkich państw członkowskich Unii Europejskiej. W ciągu ostatnich 16 lat, czyli od momentu wejścia Polski do struktur UE, uchwalanych jest średnio blisko 21 tys. stron ustaw i rozporządzeń rocznie. O ile liczba zmian przepisów ogółem od 2017 r. nieznacznie spada, o tyle w kwestiach podatkowych zauważalny jest trend rosnący. Rewolucja systemu podatkowego przyniosła nie tylko znaczne zaostrzenie przepisów, ale także wymogów sprawozdawczych, co utrudnia prowadzenie działalności gospodarczej. JPK, ceny transferowe, split payment, biała lista, STIR, MDR to niektóre z pojęć, z którymi przedsiębiorcy muszą się oswajać od niedawna. Celem niniejszego artykułu jest ocena systemu podatkowego w Polsce. Artykuł w sposób syntetyczny prezentuje również czynności legislacyjne organów skarbowych podejmowane w celu uszczelnienia luki podatkowej w Polsce. Podstawową metodę badawczą stanowi badanie ankietowe przeprowadzone wśród przedsiębiorców $\mathrm{z}$ województwa podkarpackiego oraz analiza literatury z omawianego zakresu. Przeprowadzone badania wskazują na brak stabilności oraz znaczne zmniejszenie transparentności przepisów podatkowych, a także na obciążenie przedsiębiorców wieloma dodatkowymi czynnościami mającymi za zadanie walkę administracji rządowej z szarą strefą w Polsce.
\end{abstract}

\begin{abstract}
Poland is a country with the most volatile and unpredictable legal system of almost all member states of the European Union. Over the past 16 years, i.e. since Poland's accession to the EU, nearly 21,000 pages of laws and ordinances are approved on average per year. While the total number of changes in regulations since 2017 has been slightly falling, there is a growing trend in tax issues. The revolution of the tax system has brought not only a significant tightening of regulations, but also reporting requirements, which hinders doing business. SAF-T, transfer prices, split payment, white list, STIR, or MDR, these are some of the concepts which entrepreneurs recently had to become familiar with. The aim of the article is to evaluate the tax system. The paper presents in a synthetic way the legislative activities of tax authorities taken to close the tax gap in Poland. The basic research method is a questionnaire survey conducted among entrepreneurs from the Podkarpackie Voivodeship and an analysis of the literature in this area. The conducted research indicates the instability and significant reduction in the transparency of tax regulations and also the burden on entrepreneurs with many additional activities aimed at fighting the government administration with the shadow economy in Poland.
\end{abstract}


Słowa kluczowe: akcyza; CIT; PIT; system podatkowy; VAT

Keywords: an excise tax; CIT; PIT; the tax system; VAT

Otrzymano: 30 kwietnia 2021

Received: 30 April 2021

Zaakceptowano: 1 września 2021

Accepted: 1 September 2021

Sugerowana cytacja/Suggested citation:

Nakonieczny, J., Nesterowicz, R. (2021). Ocena systemu podatkowego w opinii przedsiębiorców z województwa podkarpackiego. Przedsiębiorczość - Edukacja [Entrepreneurship - Education], 17(2), 9-25. https://doi.org/10.24917/20833296.172.1

\section{Wstęp}

W ostatnich latach liczba opracowywanych przepisów prawnych w Polsce znajdowała się na bardzo wysokim poziomie. Według raportów Grant Thornton $(2019,2021)$ w 2018 i 2019 r. uchwalono ponad 14 tys. stron głównych ustaw i rozporządzeń. W 2020 r. liczba ta nieco spadła, do poziomu 13,3 tys. stron aktów prawnych. W związku z panującą pandemią COVID-19, działania rządu skoncentrowane były wówczas w znacznym stopniu na czynnościach mających na celu zwalczanie choroby oraz ograniczanie negatywnych skutków jej występowania. W 2020 r. opracowano i wprowadzono 1,6 tys. stron „przepisów pandemicznych”. Aby nadążyć za wszystkimi zmianami, przeciętny przedsiębiorca powinien przeczytać dziennie ok. 40-45 stron przepisów i poświęcić na to blisko 2 godz. (Grant Thornton, 2021). Lata 2015-2019 to okres najbardziej intensywny dla prawa podatkowego w Polsce (Nakonieczny, 2020). Polskie organy skarbowe postawiły sobie za cel priorytetowy uszczelnienie systemu podatkowego i podjęły liczne działania w celu zmniejszenia luki podatkowej w VAT i CIT. Wymierny efekt tych czynności to aż 362 strony nowelizacji ustaw podatkowych w 2018 r. i 156 stron przepisów w 2019 r. Walka ze skutkami pandemii spowodowała, że w 2020 r. pojawiły się 94 strony ustaw podatkowych (Sejm RP, 2021, 3 kwietnia).

Wprowadzone zmiany zdeterminowały dodatkowe obowiązki sprawozdawcze i jednocześnie utrudnienie dla przedsiębiorców. Wprowadzono m.in. obowiązek sporządzania dokumentacji i analizy cen transferowych, raportowanie w formacie JPK, obowiązek przekazywania sprawozdań finansowych w wersji elektronicznej czy informacji o schematach podatkowych. Pojawiły się również nowe opłaty, które formalnie nie mają statusu podatku (tzw. podatek cukrowy i podatek od alkoholi w małych opakowaniach). Reformy systemu podatkowego przyniosły także istotne implikacje w postaci wzrostu kosztów związanych z dostosowaniem systemów finansowo-księgowych do nowych wymogów.

Celem niniejszego artykułu jest ocena systemu podatkowego w Polsce. Artykuł prezentuje również czynności legislacyjne organów skarbowych podejmowane w celu uszczelnienia luki podatkowej w Polsce. Aby zrealizować założony cel, zbudowano kwestionariusz ankiety. Badaniu poddano 28 przedsiębiorców z terenu województwa podkarpackiego. Wszystkie ankiety zostały poprawnie wypełnione i zakwalifikowane do analizy.

W artykule postawiono tezę, zgodnie z którą polski system podatkowy charakteryzuje się dużą złożonością i zmiennością, utrudniającą prowadzenie działalności gospodarczej. Opracowanie ma charakter teoretyczno-analityczny. Do realizacji podjętego tematu wykorzystano akty prawne oraz literaturę z zakresu rachunkowości podatkowej. 


\section{Przegląd literatury}

Termin „system podatkowy” jest szeroko rozpowszechniony i stale wykorzystywany w aktach prawnych, orzeczeniach sądowych, badaniach naukowych i środkach masowego przekazu. W literaturze przedmiotu funkcjonuje wiele jego węższych i szerszych definicji. Najogólniej system podatkowy można określić jako zespół elementów wzajemnie ze sobą powiązanych oraz uzależnionych od siebie, które tworzą wspólną całość (Mastalski, 2000). Niektóre definicje utożsamiają system podatkowy z podatkami. W tym ujęciu system podatkowy to zbiór zintegrowanych i wewnętrznie spójnych podatków obowiązujących w danym kraju (Ofiarski, 2013). System podatkowy to także całokształt podatków występujących $\mathrm{w}$ określonym czasie, w danym państwie, wzajemnie ze sobą powiązanych i od siebie uzależnionych, tworzących pewną całość (Dzwonkowski, 2010; Walczak, 2003). L. Bylicki (2016) zwraca jednak uwagę na fakt, że sprowadzanie systemu podatkowego do kategorii podatku jest zbyt dużym uproszczeniem. System podatkowy to także szereg regulacji, takich jak krajowe i międzynarodowe prawo podatkowe, oraz organy administracji rządowej i samorządowej (Podatki.gov.pl, 2021).

System podatkowy można także rozpatrywać z punktu widzenia pełnionych przez niego funkcji. Do głównych funkcji zalicza się funkcję: fiskalną, redystrybucyjną, stymulacyjną (Mikrut, Poznańska, 2009) oraz informacyjną o jego przebiegu (Pach, 2017). Przyjmuje się, że najważniejsze znaczenie ma funkcja fiskalna, która decyduje o konstrukcji podatków. Zadaniem podatków jest pokrycie głównych wydatków budżetowych. W tym kontekście system podatkowy jest mechanizmem, który zasila „sektor publiczny w podstawowy strumień środków finansujących jego działalność" (Żyżyński, 2009: 55). Drugą, równie istotną, funkcją systemu podatkowego jest funkcja redystrybucyjna polegająca na odpowiednim podziale dochodów oraz majątku pomiędzy państwem a podatnikami (Ofiarski, 2013). Można zatem przyjąć, że system podatkowy to pobór przychodów ze wszystkich tytułów podatkowych, które występują w danym kraju, w celu ich redystrybucji na zabezpieczenie usług publicznych realizowanych przez rząd i samorządy oraz polityki społeczne (Making Tax Simpler..., 2015). Funkcja stymulacyjna natomiast ma za zadanie pobudzanie procesów gospodarczych oraz inwestycyjnych, a także rozwoju społecznego m.in. poprzez regulowanie wysokości obciążeń podatkowych oraz tworzenie warunków do budowy nowych miejsc pracy (Wach, 2005). Z tej perspektywy system podatkowy można zdefiniować jako całokształt podatków obowiązujących i stosowanych przez określone państwo w określonym czasie, który powinien sprzyjać rozwojowi gospodarczemu, powstawaniu nowych miejsc pracy oraz mobilizować do większej aktywności zawodowej (Wach, 2005). Biorąc pod uwagę całokształt funkcjonalności systemu podatkowego oraz relacje zachodzące w polityce społeczno-gospodarczej, warto przytoczyć także definicję systemu podatkowego opracowaną przez K. Raczkowskiego. Według tego badacza system podatkowy to „wspólna baza danin publicznych, ustanawiana i egzekwowana przez przepisy organizacyjno-prawne, instytucje finansowe (a w przypadku UE - również wspólnotowe), gospodarstwa domowe czy przedsiębiorstwa zorientowane na podnoszenie konkurencyjności gospodarki narodowej i maksymalizację dobrobytu społecznego" (Raczkowski, 2016: 75).

Niezależnie od przyjętej definicji, optymalny system podatkowy powinien łączyć skutecznie funkcje fiskalne i pozafiskalne. Powinien być spójny, kompletny, stabilny i nieskomplikowany. Powinien determinować rozwój gospodarczy (Mazurek-Chwiejczak, 2016). J.E. Stiglitz wymienia pięć cech sprawnie funkcjonującego systemu podatkowego, 
które w większości oparte są na zasadach podatkowych sformułowanych przez A. Smitha i A. Wagnera. Należą do nich:

- efektywność ekonomiczna, w myśl której system podatkowy nie powinien przeszkadzać w efektywnej alokacji zasobów,

- prostota administracyjna, oznaczająca, że system podatkowy powinien być prosty i relatywnie tani w zarządzaniu,

- elastyczność, zgodnie z którą system podatkowy powinien reagować bez problemu na zmiany warunków gospodarowania,

- odpowiedzialność polityczna, umożliwiająca dostęp podatnikom do informacji, dotyczącej wielkości ich obciążeń podatkowych oraz pozwalająca na ocenę, w jakim stopniu system jest transparentny,

- uczciwość, oznaczająca, że system podatkowy powinien sprawiedliwie traktować poszczególnych podatników (Stiglitz, 2004).

Rozwój systemu podatkowego jest uwarunkowany kwestiami historycznymi oraz otoczeniem, które narzuca pewne rozwiązania. Budowa optymalnego systemu wymaga uwzględnienia postulatów prawno-ekonomicznych, które dotyczą przede wszystkim transparentności, wewnętrznej spójności oraz logicznej struktury aktów prawnych (Czubakowska, Grodzińska, 2013). Istotnymi kwestiami są zwłaszcza: zachowanie równowagi pomiędzy interesem podatnika a interesem państwa, współpraca wszystkich grup interesariuszy na poziomie tworzenia prawa podatkowego oraz brak wykorzystywania prawa podatkowego do zaspokajania interesów politycznych (System..., 2014). Zdaniem J. Komorowskiego głównymi celami systemu podatkowego w XXI w. powinny być: „stymulowanie pożądanych procesów gospodarczych, przemian strukturalnych, zachowań podatkowych, ograniczanie rozległości szarej strefy, odpowiedź na wyzwania globalizacji, działalność wielkich korporacji, międzynarodowych operacji finansowych czy rajów podatkowych” (Komorowski, 2007: 237). Realizacja tych celów narzuca pewne działania administracji skarbowej, które spotykają się z większą lub mniejszą niechęcią ze strony podatników.

Obowiązujący obecnie w Polsce system podatkowy został ukształtowany pod wpływem wielu czynników zarówno wewnętrznych, jak i zewnętrznych, takich jak: gospodarka centralnie planowana, przemiany gospodarcze i społeczno-ustrojowe po 1989 r., reformy podatków dochodowych w 1992 r., wprowadzenie podatku od towarów i usług (VAT) w 1993 r., reforma Krajowej Administracji Skarbowej oraz harmonizacja polskiego prawa podatkowego z prawem unijnym (Bylicki, 2016; Pach, 2017, 2018). Polski system podatkowy przeszedł szereg zmian, zanim został przystosowany do wymogów gospodarki rynkowej. I w dalszym ciągu ewoluuje i dostosowuje się do ogólnoświatowych tendencji.

\section{Analiza czynności legislacyjnych polskich organów skarbowych}

Dla przedsiębiorców stabilne i jasne przepisy są kluczowe w prowadzeniu działalności gospodarczej. Tymczasem w kraju od paru lat można zaobserwować dużą zmienność w zakresie prawa podatkowego. W ciągu ostatnich 11 lat aparat rządowy pracował bardzo intensywnie w tej kwestii (rycina 1).

Biorąc pod uwagę ostatnie dziesięciolecie, najwięcej przepisów (bez umów międzynarodowych) uchwalono w 2015 i 2016 r., odpowiednio 29843 i 31906 stron. Rok 2018 odznaczał się spadkiem liczby uchwalonych ustaw i rozporządzeń o blisko połowę w stosunku do 2017 r. W 2019 r. zaobserwowano kolejne nasilenie publikacji aktów prawnych. 
Rycina 1. Liczba stron aktów prawnych oraz udział ustaw podatkowych w ogóle aktów prawnych w Polsce w latach 2010-2020

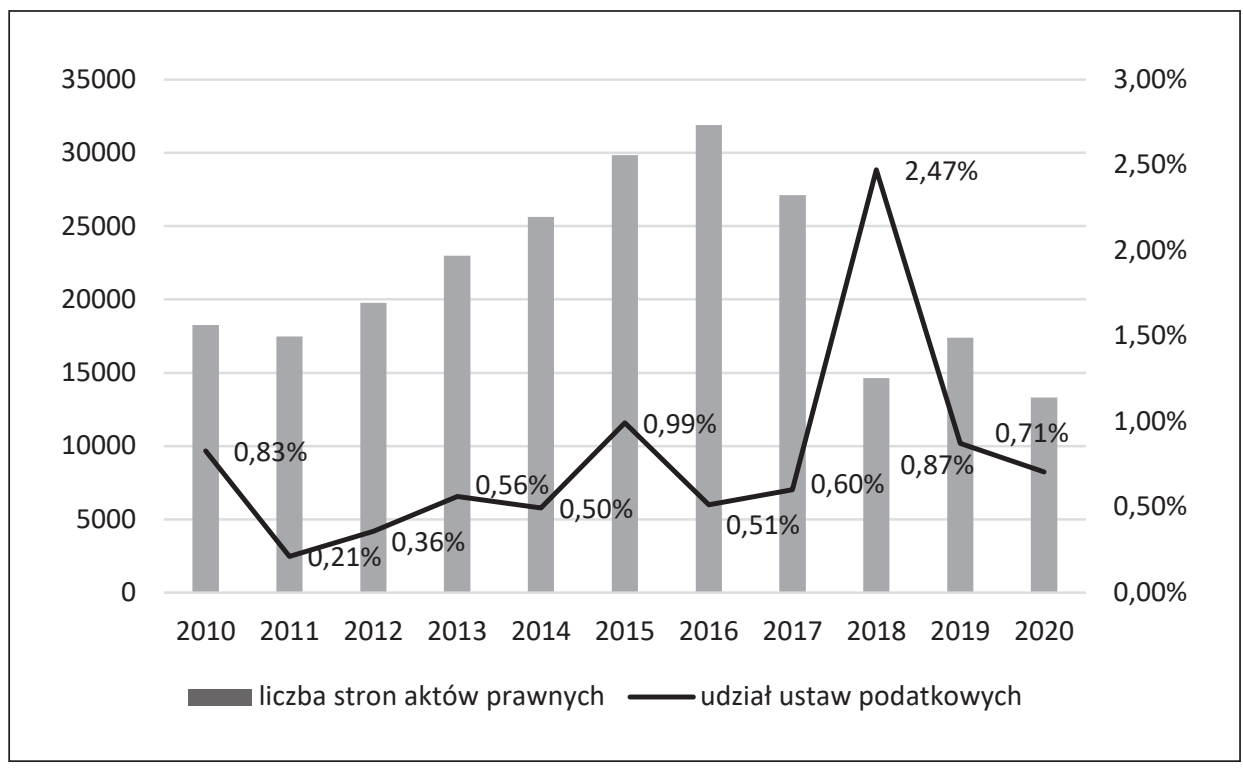

Źródło: Opracowanie własne na podstawie: www.sejm.gov.pl

W pewnym stopniu za taką sytuację odpowiada członkostwo Polski w strukturach Unii Europejskiej i obowiązek implementacji części przepisów unijnych do krajowego prawodawstwa. Część działań determinowana jest natomiast prowadzoną polityką w zakresie uszczelniania systemu podatkowego.

Rok 2020 był szczególnym okresem ze względu na panującą pandemię i trudno wpisać go do panującego trendu działalności legislacyjnej. Tym samym trudno wysunąć na podstawie badań wiążące wnioski. Niemniej jednak był to rok, w którym uwaga skupiona była przede wszystkim na przepisach „covidowych”. Działania te spowodowały zmniejszenie liczby uchwalonych ustaw o 25\% w stosunku do 2019 r.

Udział ustaw podatkowych w ogóle przepisów prawnych był stosunkowo niewielki i wyniósł najwyżej 2,47\% w 2018 r. W pozostałych latach objętych analizą nie przekroczył progu $1 \%$. Biorąc jednak pod uwagę liczbę stron opublikowanych przepisów podatkowych, sytuacja wygląda zupełnie inaczej (rycina 2). Zdaniem autorów raportu Barometr Prawa (Grant Thornton, 2019) rok 2018 był jednym z najbardziej niestabilnych pod względem prawa podatkowego od początków transformacji w Polsce w 1989 r. Nastąpił wówczas ponad dwukrotny wzrost liczby stron uchwalonych ustaw w porównaniu z 2017 r. i ponad ośmiokrotny w stosunku do 2009 r.

Na taki wzrost w największym stopniu miały wpływ zmiany w podatku dochodowym od osób fizycznych, które objęły 101 stron maszynopisu, oraz w Ordynacji podatkowej i podatku dochodowym od osób prawnych - odpowiednio 74 i 72 strony. Natomiast najmniejsze zmiany dotyczyły podatku VAT - zaledwie 13 stron (rycina 3). Pakiet modyfikacji podatkowych uchwalonych w 2018 r. obejmował m.in.: zasady opodatkowania wygranych w grach hazardowych, zasady określające uprawnienia do korzystania z 50\% kosztów uzyskania przychodów, przepisy dotyczące zasad opodatkowania podatkiem 
Rycina 2. Liczba stron ustaw podatkowych ogółem



Źródło: Opracowanie własne na podstawie: www.sejm.gov.pl

Rycina 3. Liczba stron ustaw podatkowych z podziałem na poszczególne podatki

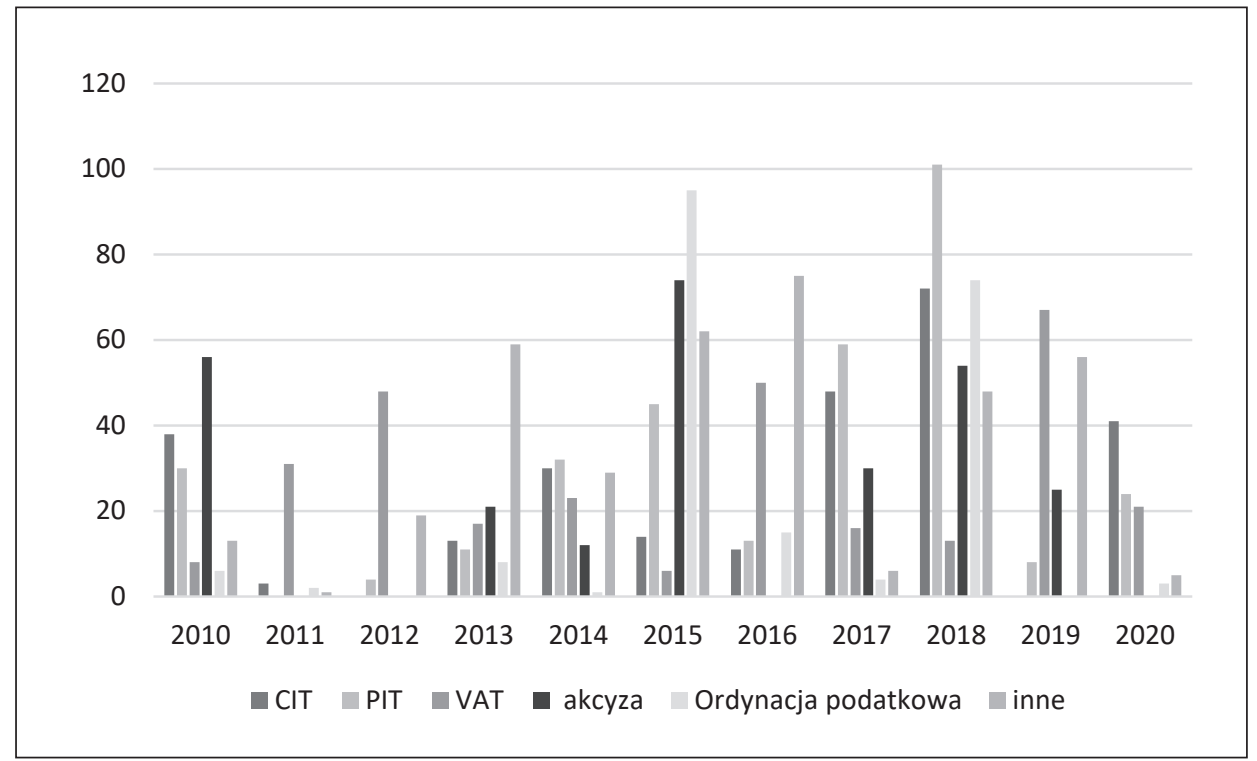

Źródło: Opracowanie własne na podstawie: www.sejm.gov.pl

dochodowym od osób fizycznych dochodów uzyskiwanych ze zbycia akcji nabytych w ramach tzw. programów motywacyjnych, sposoby blokady rachunku podmiotu kwalifikowanego, wprowadzenie definicji pełnomocnika do rachunku podmiotu kwalifikowanego, wprowadzenie usługi pozwalającej na automatyczne wypełnianie przez Krajową 
Administrację Skarbową zeznań podatkowych PIT, zmianę wysokości progów dokumentacyjnych, po przekroczeniu których powstaje obowiązek sporządzenia dokumentacji cen transferowych, zastąpienie obowiązku składania przez podatników sprawozdań CIT/TP lub PIT/TP raportowaniem cen transferowych w formie elektronicznej (TPR), ujednolicenie wymogów dokumentacyjnych ze standardami OECD czy wprowadzenie stawki $9 \%$ CIT dla podatników, u których przychody osiągnięte w roku podatkowym nie przekroczyły wyrażonej w złotych kwoty odpowiadającej równowartości 1200000 euro.

Rok 2019 zdominowany został licznymi zmianami przede wszystkim w przepisach o podatku od towarów i usług VAT, co skutkowało opublikowaniem 67 stron maszynopisu. Oznacza to wzrost w porównaniu z 2018 r. o 19\%. Wprowadzono w tym zakresie przede wszystkim rozwiązania dotyczące: stosowania kas rejestrujących (kas online) do ewidencji sprzedaży i podatku należnego ze sprzedaży na rzecz osób fizycznych nieprowadzących działalności gospodarczej, publikacji na stronie Ministerstwa Finansów wykazu zawierającego informacje o podatnikach zarejestrowanych jako podatnicy VAT czynni, zmian w zakresie solidarnej odpowiedzialności, likwidacji odwrotnego obciążenia w obrocie krajowym i wprowadzenia w jego miejsce obowiązkowego mechanizmu podzielonej płatności, nowej matrycy stawek VAT oraz wiążącej informacji stawkowej (WIS). Część uchwalonych ustaw weszła w życie dopiero w 2020 r. Mniej zmian dotyczyło podatku akcyzowego - 25 stron maszynopisu - oraz podatku dochodowego od osób fizycznych 8 stron. Pomimo iż wprowadzono znacznie mniej modyfikacji w przepisach w porównaniu z 2018 r., były to zmiany istotne, ponieważ dotyczyły większości podatników. Zdaniem autorów raportu Barometr Prawa (Grant Thornton, 2020) od połowy 2018 r. do końca 2019 r. wymieniona została na nową prawie jedna trzecia treści ustaw podatkowych.

Chociaż rok 2020 podporządkowany został w znacznej mierze ustawom „covidowym”, to wprowadzone zmiany podatkowe były bardzo istotne z punktu widzenia przedsiębiorców. Dotyczyły one przede wszystkim podatku dochodowego od osób prawnych, podatku dochodowego od osób fizycznych oraz podatku od towarów i usług. Przedsiębiorcy musieli zmierzyć się z tzw. białą listą podatników VAT i związaną z tym weryfikacją rachunków bankowych kontrahentów, przeniesieniem elementów z deklaracji VAT-7 (VAT-7K) do nowej deklaracji w postaci pliku JPK_VDEK, co spowodowało konieczność wprowadzenia dodatkowych oznaczeń identyfikujących charakter dokonywanych transakcji, odejście od klasyfikacji PKWiU 2008 na rzecz Nomenklatury Scalonej w odniesieniu do towarów oraz PKWiU 2015 w zakresie usług. Wprowadzono także możliwość zapłaty zobowiązań podatkowych z zakresu PIT, CIT, VAT i niepodatkowych należności budżetowych na jeden indywidualny rachunek podatkowy. Wśród uchwalonych ustaw podatkowych, które wejdą w życie w 2021 r., znalazły się m.in. tzw. CIT estoński, pakiet Slim VAT i obowiązek publikowania informacji o realizowanej strategii podatkowej przez niektóre grupy podmiotów. Niektóre nowelizacje przepisów nabrały wręcz charakteru rewolucyjnego, jak np. zmiany w sposobie opodatkowania spółek komandytowych. Częstotliwość zmian przepisów podatkowych w latach 2018-2020 zaprezentowano na rycinie 4.

W kontekście tak dużej zmienności przepisów oraz złożoności prawa podatkowego niezwykle istotną kwestią wydaje się być możliwość ubiegania się podatników o udzielenie indywidualnej interpretacji przepisów, co umożliwia m.in. obowiązująca Konstytucja Biznesu (Biznes.gov.pl, 2021, 28 marca). Praktyka gospodarcza tymczasem wskazuje na pewne trudności w tym zakresie, ponieważ znaczna część wniosków składanych przez przedsiębiorców do Krajowej Informacji Skarbowej (KIS) zostaje odrzucona lub pozostawiona 
Rycina 4. Częstotliwość zmian pięciu głównych ustaw podatkowych w latach 2018-2020

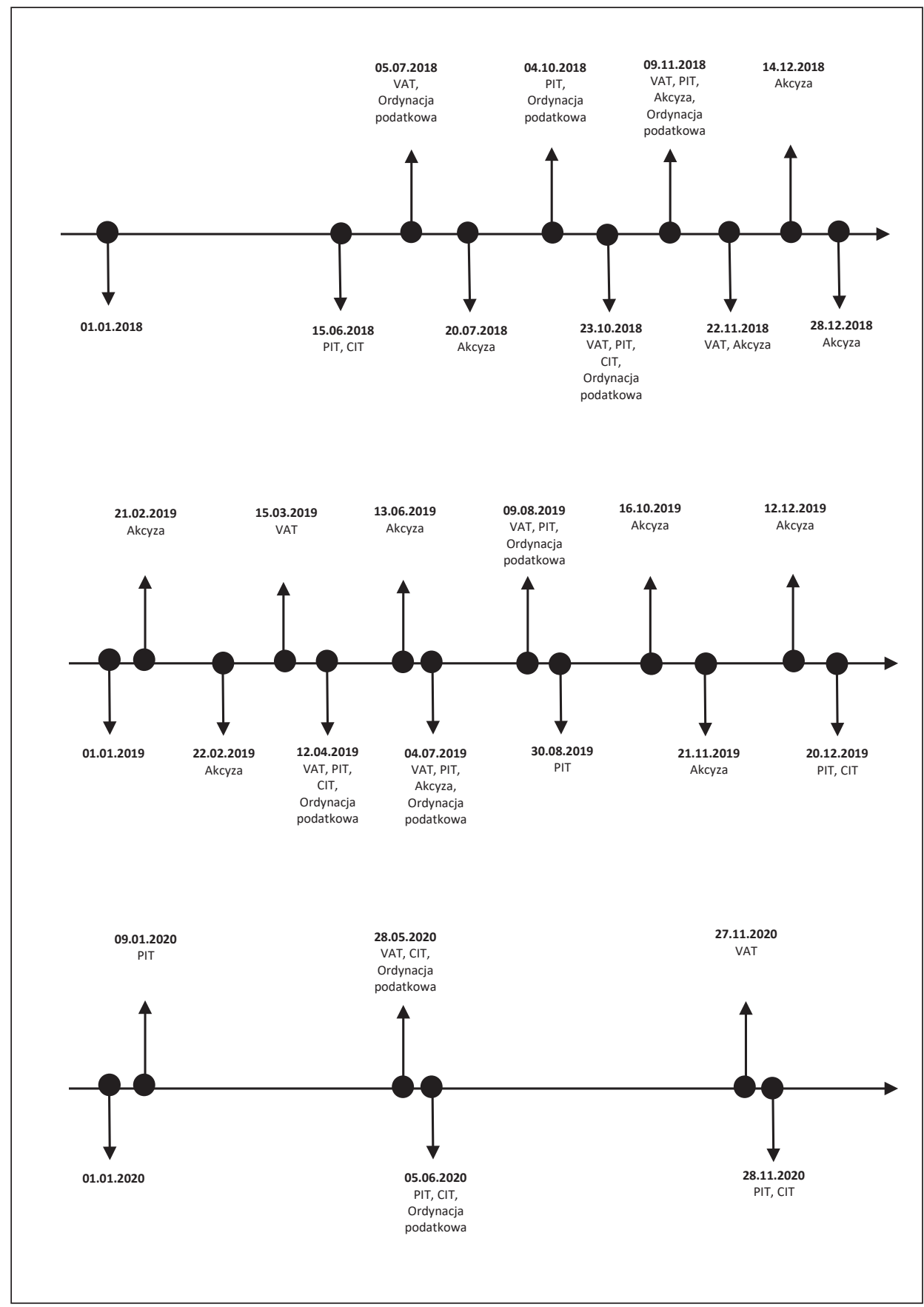

Źródło: Opracowanie własne 
bez rozpatrzenia. W 2019 r. do Krajowej Informacji Skarbowej wpłynęło 26812 wniosków o wydanie interpretacji indywidualnych, z czego 1346 zakończyło się odmową, a w przypadku 3995 wydano postanowienia o pozostawieniu wniosku bez rozpatrzenia. Należy zaznaczyć także, że wśród wszystkich wydanych interpretacji (21 032), aż 30\% stanowiły interpretacje nieprawidłowe (Krajowa Administracja Skarbowa, 2020). W 2020 r. do KIS wpłynęło o 1414 wniosków mniej, z czego najwięcej dotyczyło podatku VAT (11 562). 1496 wniosków zakończyło się odmową, 5446 wniosków stanowiły interpretacje nieprawidłowe, natomiast 3824 wnioski pozostawiono bez rozpatrzenia. Złożono łącznie 1008 skarg na wydane interpretacje indywidualne (Krajowa Administracja Skarbowa, 2021).

\section{Ocena systemu podatkowego przez przedsiębiorców}

Badanie polskiego systemu podatkowego przeprowadzono wśród przedsiębiorców z obszaru województwa podkarpackiego. W tym celu opracowano anonimową ankietę, której celem było uzyskanie opinii respondentów na temat otoczenia podatkowego spółek oraz wskazanie propozycji zmian ułatwiających prowadzenie działalności gospodarczej. W badaniu wzięło udział 28 przedsiębiorstw, z czego 53,6\% stanowiły przedsiębiorstwa duże, $21,4 \%$ - przedsiębiorstwa średnie, 17,9\% - przedsiębiorstwa małe, a 7,1\% - mikroprzedsiębiorstwa. Najliczniejszą grupę stanowiły podmioty świadczące usługi - 71,4\%, branżę handlową reprezentowało 5 podmiotów, a branżę produkcyjną - 4 podmioty.

Ankietyzację przeprowadzono w lipcu i sierpniu 2021 r. Ankieta skierowana była przede wszystkim do dyrektorów finansowych, głównych księgowych, osób zajmujących się sprawozdawczością finansową oraz przedstawicieli kadry zarządzającej.

W pierwszej kolejności respondenci zostali poproszeni o wyrażenie opinii dotyczącej poszczególnych elementów systemu podatkowego w Polsce (tabela 1).

Tabela 1. Ocena poszczególnych elementów systemu podatkowego (udział w \%)

\begin{tabular}{|l|c|c|c|c|c|}
\hline \multirow{2}{*}{\multicolumn{1}{|c|}{ Wyszczególnienie }} & \multicolumn{5}{c|}{ Ocena } \\
\cline { 2 - 6 } & bardzo zła & zła & średnia & dobra & $\begin{array}{c}\text { bardzo } \\
\text { dobra }\end{array}$ \\
\hline $\begin{array}{l}\text { Przejrzystość przepisów } \\
\text { podatkowych }\end{array}$ & $14,29 \%$ & $46,43 \%$ & $39,29 \%$ & $0,00 \%$ & $0,00 \%$ \\
\hline Stabilność przepisów podatkowych & $25,00 \%$ & $50,00 \%$ & $21,43 \%$ & $3,57 \%$ & $0,00 \%$ \\
\hline $\begin{array}{l}\text { Odpowiednio wczesne } \\
\text { informowanie o planowanych } \\
\text { zmianach w prawie podatkowym }\end{array}$ & $21,43 \%$ & $39,29 \%$ & $32,14 \%$ & $7,14 \%$ & $0,00 \%$ \\
\hline $\begin{array}{l}\text { Dostępność do indywidualnej } \\
\text { interpretacji przepisów }\end{array}$ & $17,86 \%$ & $32,14 \%$ & $39,29 \%$ & $10,71 \%$ & $0,00 \%$ \\
\hline $\begin{array}{l}\text { Relacje pomiędzy administracją } \\
\text { skarbową a przedsiębiorcą }\end{array}$ & $7,14 \%$ & $10,71 \%$ & $71,43 \%$ & $10,71 \%$ & $0,00 \%$ \\
\hline $\begin{array}{l}\text { Spójność pomiędzy poszczególnymi } \\
\text { aktami prawnymi }\end{array}$ & $14,29 \%$ & $60,71 \%$ & $21,43 \%$ & $3,57 \%$ & $0,00 \%$ \\
\hline
\end{tabular}

Źródło: Opracowanie własne 
Zdecydowana większość respondentów źle oceniła przejrzystość przepisów podatkowych (46,43\%), ich stabilność (50\%) oraz spójność pomiędzy poszczególnymi aktami prawnymi (60,71\%). Także 25\% ankietowanych zdecydowało się na zaznaczenie opcji „bardzo źle” w przypadku stabilności przepisów. Jedynie 3,57\% badanych zmienność przepisów oceniła pozytywnie. Dużym problemem dla przedsiębiorców okazały się również terminy informowania o planowanych zmianach w prawie podatkowym oraz dostępność do indywidualnej interpretacji przepisów. W pierwszym przypadku było to 60,72\%, w drugim - połowa badanych (jednocześnie opcja „bardzo zła” i „zła”). Najkorzystniej w tym zestawieniu wypadła pozycja dotycząca relacji pomiędzy organami skarbowymi a podatnikiem, którą ankietowani ocenili w ponad 70\% jako średnią oraz w 10,71\% jednocześnie jako złą i dobrą. Żaden $\mathrm{z}$ ankietowanych nie ocenił wymienionych elementów systemu podatkowego bardzo dobrze.

Najbardziej problematyczne dla podatników okazały się kwestie związane z raportowaniem schematów podatkowych MDR (Mandatory Disclosure Rules), które łącznie blisko 70\% respondentów uznało za średnio i bardzo problematyczne (tabela 2). Jest to dodatkowy obowiązek raportowy, który dostarcza informacji o sposobach optymalizacji podatkowej przedsiębiorców (ustawa z dnia 29 sierpnia 1997; ustawa z dnia 23 października 2018). Zaimplementowanie przepisów wynikało z dyrektywy Rady (UE) 2018/822 z 25 maja 2018 roku.

Tabela 2. Problematyczność poszczególnych kwestii podatkowych (udział w \%)

\begin{tabular}{|c|c|c|c|c|c|}
\hline Wyszczególnienie & 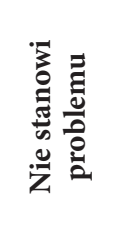 & 芯 & 导 & 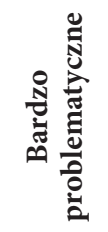 & 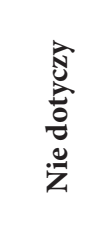 \\
\hline $\begin{array}{l}\text { Mechanizm podzielonej } \\
\text { płatności }\end{array}$ & $28,57 \%$ & $25,00 \%$ & $17,86 \%$ & $21,43 \%$ & $7,14 \%$ \\
\hline Biała lista podatników VAT & $35,71 \%$ & $28,57 \%$ & $21,43 \%$ & $10,71 \%$ & $3,57 \%$ \\
\hline Ceny transferowe & $0,00 \%$ & $10,71 \%$ & $17,86 \%$ & $46,43 \%$ & $25,00 \%$ \\
\hline $\begin{array}{l}\text { Stosowanie kas } \\
\text { rejestrujących online }\end{array}$ & $17,86 \%$ & $21,43 \%$ & $39,29 \%$ & $3,57 \%$ & $17,86 \%$ \\
\hline $\begin{array}{l}\text { Pobór podatku u źródła od } \\
\text { płatności za granicę }\end{array}$ & $3,57 \%$ & $10,71 \%$ & $50,00 \%$ & $10,71 \%$ & $25,00 \%$ \\
\hline $\begin{array}{l}\text { Raportowanie schematów } \\
\text { podatkowych MDR }\end{array}$ & $0,00 \%$ & $3,57 \%$ & $14,29 \%$ & $53,57 \%$ & $28,57 \%$ \\
\hline Rozliczanie podatku VAT & $10,71 \%$ & $25,00 \%$ & $39,29 \%$ & $21,43 \%$ & $3,57 \%$ \\
\hline Rozliczenie podatku CIT & $17,86 \%$ & $28,57 \%$ & $35,71 \%$ & $14,29 \%$ & $3,57 \%$ \\
\hline $\begin{array}{l}\text { Liczba sprawozdań } \\
\text { przekazywanych organom } \\
\text { skarbowym }\end{array}$ & $10,71 \%$ & $25,00 \%$ & $14,29 \%$ & $46,43 \%$ & $3,57 \%$ \\
\hline CIT estoński & $0,00 \%$ & $3,57 \%$ & $21,43 \%$ & $7,14 \%$ & $67,86 \%$ \\
\hline $\begin{array}{l}\text { WDT w transakcjach } \\
\text { łańcuchowych }\end{array}$ & $3,57 \%$ & $3,57 \%$ & $21,43 \%$ & $35,71 \%$ & $35,71 \%$ \\
\hline
\end{tabular}

Źródło: Opracowanie własne 
Kłopotliwe dla przedsiębiorców były również: kwestie dotyczące cen transferowych (64,29\%), duża liczba sprawozdań przekazywanych organom skarbowym, ogólne czynności mające na celu rozliczenie podatku VAT w przedsiębiorstwie (obie odpowiedzi po $60,72 \%)$ oraz pobór podatku u źródła od płatności za granicę $(60,71 \%)$. Nieco mniej ankietowanych wskazuje na trudności w obszarze związanym $\mathrm{z}$ wewnątrzwspólnotową dostawą towarów w transakcjach łańcuchowych. Odpowiedzi takiej udzieliło 57,14\% respondentów. Z kolei za najmniej problematyczne ankietowani uznali obszary dotyczące białej listy podatników VAT oraz mechanizmu podzielonej płatności, które nie stanowiły problemu lub były mało problematyczne odpowiednio dla 64,28\% i 53,57\% respondentów. Wprowadzenie przez administrację skarbową rejestru podatników VAT, tzw. białej listy (ustawa z dnia 12 kwietnia 2019) narzuca obowiązek weryfikacji kontrahenta podczas przeprowadzania transakcji oraz dokonywania zapłaty wyłącznie na rachunki figurujące na liście. Zasadniczym utrudnieniem, na które wskazali ankietowani w tym przypadku, jest konieczność weryfikacji kontrahenta na dzień zlecenia przelewu, zwłaszcza dla płatności w transzach. Z kolei wdrożenie do praktyki biznesowej mechanizmu podzielonej płatności (Komisja Europejska, 2016) od samego początku budziło wiele emocji z uwagi na obawę utraty płynności finansowej przez przedsiębiorstwa. Regulacja ta ma za zadanie ułatwienie organom podatkowym monitorowania środków pieniężnych na rachunkach bankowych VAT oraz sprawowanie nadzoru nad ich uwalnianiem, co powoduje, że dysponowanie środkami zgromadzonymi na rachunku VAT jest ograniczone (Szymankiewicz, 2019). Jednak wyniki badań wskazują na to, iż przedsiębiorcy szybko oswoili się z oboma mechanizmami na tyle, że nie stanowiły one dla nich większego problemu.

W odpowiedzi na pytanie dotyczące przedłożenia organom skarbowym informacji dotyczącej raportowania schematów podatkowych, $85,72 \%$ respondentów odpowiedziało przecząco, z czego blisko 40\% każdorazowo weryfikowało, czy powinno takiego obowiązku dopełnić. Jedynie 4 podmioty spośród badanych złożyło informacje MDR jeden raz (rycina 5).

Przyjęta strategia uszczelnienia systemu podatkowego w Polsce zmusiła instytucje rządowe do wprowadzenia szeregu konstrukcji prawno-podatkowych mających charakter czynności doraźnych, tymczasowych, a także innowacyjnych rozwiązań systemowych, które nie tylko budzą liczne emocje wśród przedsiębiorców, ale także w różny sposób wpływają na zmniejszenie luki podatkowej. Zdaniem przedsiębiorców biorących udział w badaniu, w największym stopniu na uszczelnienie systemu podatkowego w Polsce ma wpływ ex aequo wprowadzenie mechanizmu podzielonej płatności oraz stosowanie białej listy podatników VAT. Takiego zdania było blisko 79\% respondentów (rycina 6). Na drugim i trzecim miejscu znalazły się raportowanie schematów podatkowych oraz nowe zasady poboru podatku u źródła. Takiej odpowiedzi udzieliło odpowiednio 60,71\% i 57,14\% przedsiębiorców. Natomiast najmniejsze znaczenie w tym przypadku mają zmiany w podatku dochodowym od osób fizycznych (PIT).

Ankietowani zwrócili uwagę na jeszcze jeden obszar związany ze zmianą w regulacjach podatkowych, który ich zdaniem przyczyni się do zwiększenia wpływów budżetowych z tytułu podatków. Jest to działanie polegające na wprowadzeniu przez administrację skarbową Krajowego Systemu e-Faktur (KSeF). Takiego zdania było 75\% ankietowanych.

Następnie w badaniu poruszono problematykę Programu Współdziałania, funkcjonującego pod nazwą Monitoring Horyzontalny (Horizontal Monitoring Compliance). Podstawowym założeniem tego programu jest współpraca dużych przedsiębiorców 
Rycina 5. Przedłożenie organom skarbowym informacji w zakresie raportowania schematów podatkowych

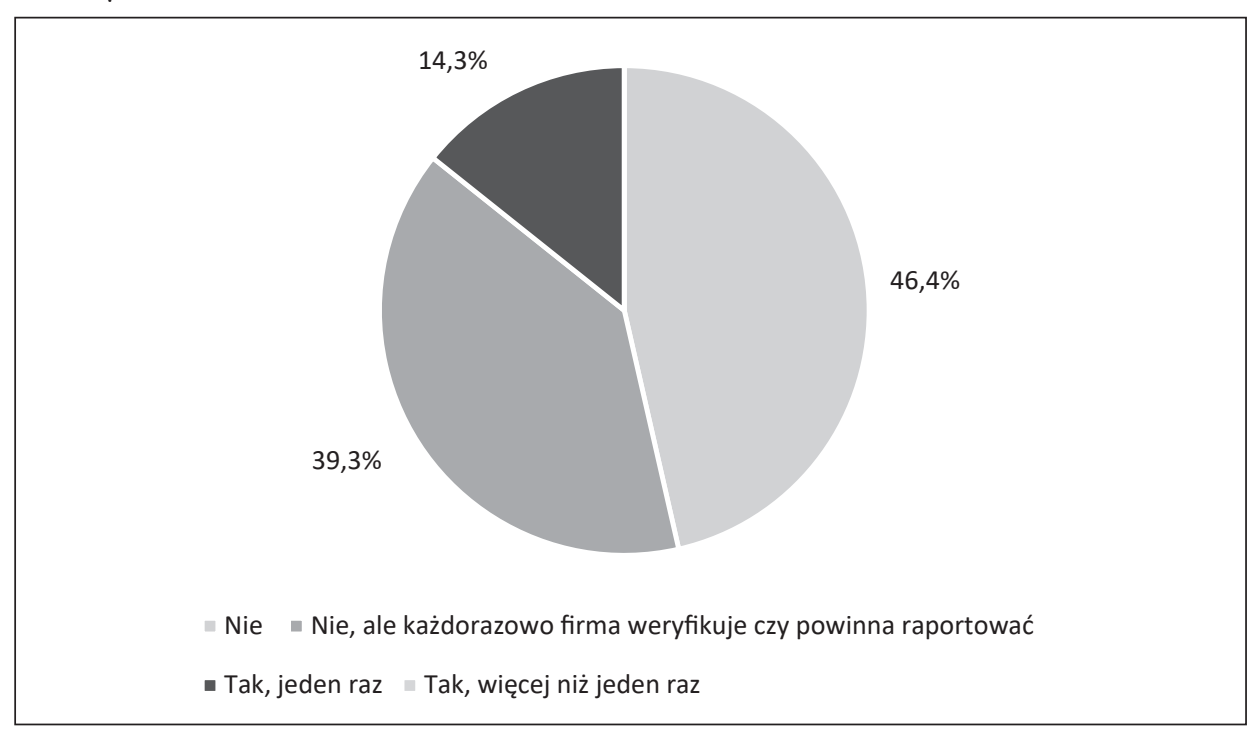

Źródło: Opracowanie własne

Rycina 6. Działania administracji skarbowej wpływające, w opinii respondentów, w największym stopniu na uszczelnienie systemu podatkowego

\begin{tabular}{|c|c|}
\hline Mechanizm podzielonej płatności & $78,57 \%$ \\
\hline Biała lista podatników VAT & $78,57 \%$ \\
\hline Raportowanie schematów podatkowych & $60,71 \%$ \\
\hline Nowe zasady poboru podatku u źródła & $57,14 \%$ \\
\hline Stosowanie kas rejestrujących online & $53,57 \%$ \\
\hline Ceny transferowe & $50,00 \%$ \\
\hline Wprowadzenie pakietu e-commerce & $50,00 \%$ \\
\hline Zmiany w podatku PIT & $46,43 \%$ \\
\hline
\end{tabular}

Źródło: Opracowanie własne

(w pierwszej kolejności) z organami skarbowymi, oparta na wzajemnym zaufaniu i wykraczająca poza ustawowe obowiązki, celem przestrzegania prawa podatkowego (Podatki. gov.pl., 2021, 9 sierpnia). Z przeprowadzonego badania wynika, że aż 75\% ankietowanych nie wiedziało, czym jest Monitoring Horyzontalny. 25\% badanych przedsiębiorców nie zamierzało nawiązać w przyszłości dobrowolnej współpracy z Krajową Administracją Skarbową w przypadku rozszerzenia kryteriów do objęcia monitoringiem, natomiast 71,42\% uczestników badania nie wykluczało takiej możliwości. Jedynie jeden podmiot miał zamiar skorzystać z tego programu. 
Działania legislacyjne organów skarbowych przyczyniły się do rozszerzenia zakresu odpowiedzialności osób zarządzających podmiotami gospodarczymi i wprowadzenia szeregu kar finansowych. W związku $\mathrm{z}$ tym respondenci zostali zapytani o procedury związane z przeciwdziałaniem poniesieniu odpowiedzialności karnej skarbowej przez kadrę zarządzającą w ich spółkach (rycina 7).

Badania wykazały, że w przypadku 9 podmiotów $(32,14 \%)$ nie przeprowadzono żadnych czynności z tym związanych. Jedynie 4 podmioty spośród badanych wdrożyły do tej pory pewne procedury, a 3 spółki $(10,71 \%)$ deklarowały takie plany. Natomiast blisko $43 \%$ ankietowanych nie miało wiedzy na ten temat. Jednocześnie $1 / 4$ ankietowanych stwierdziła, iż rozwój regulacji rozszerzających odpowiedzialność karną skarbową spółek oraz osób zarządzających przedsiębiorstwem nie przyczynił się do powstania trudności związanych z zatrudnianiem osób na konkretne stanowiska (rycina 8). Również 25\% respondentów twierdziło, iż taki wpływ miał miejsce, z czego 3 podmioty uznały wpływ za znaczący, a 4 za nieutrudniający prowadzenia działalności. Połowa ankietowanych nie miała informacji na ten temat.

W ostatnim pytaniu ankietowani zostali poproszeni o podanie własnych propozycji dotyczących zmian w systemie podatkowym, które przyczyniłyby się do ułatwienia prowadzenia działalności gospodarczej. Wśród takich zmian respondenci najczęściej wskazywali na ujednolicenie przepisów podatkowych, większą stabilizację prawa podatkowego i związane z tym odpowiednio wczesne informowanie podatników o zmianach przepisów. Przedsiębiorcy postulowali również transparentność przepisów, ich jasną interpretację przez organy skarbowe oraz zwiększenie liczby interpretacji ogólnych, formalnie wiążących dla wszystkich organów podatkowych.

Rycina 7. Wprowadzenie procedur związanych z przeciwdziałaniem poniesieniu odpowiedzialności karnej skarbowej przez kadrę zarządzającą

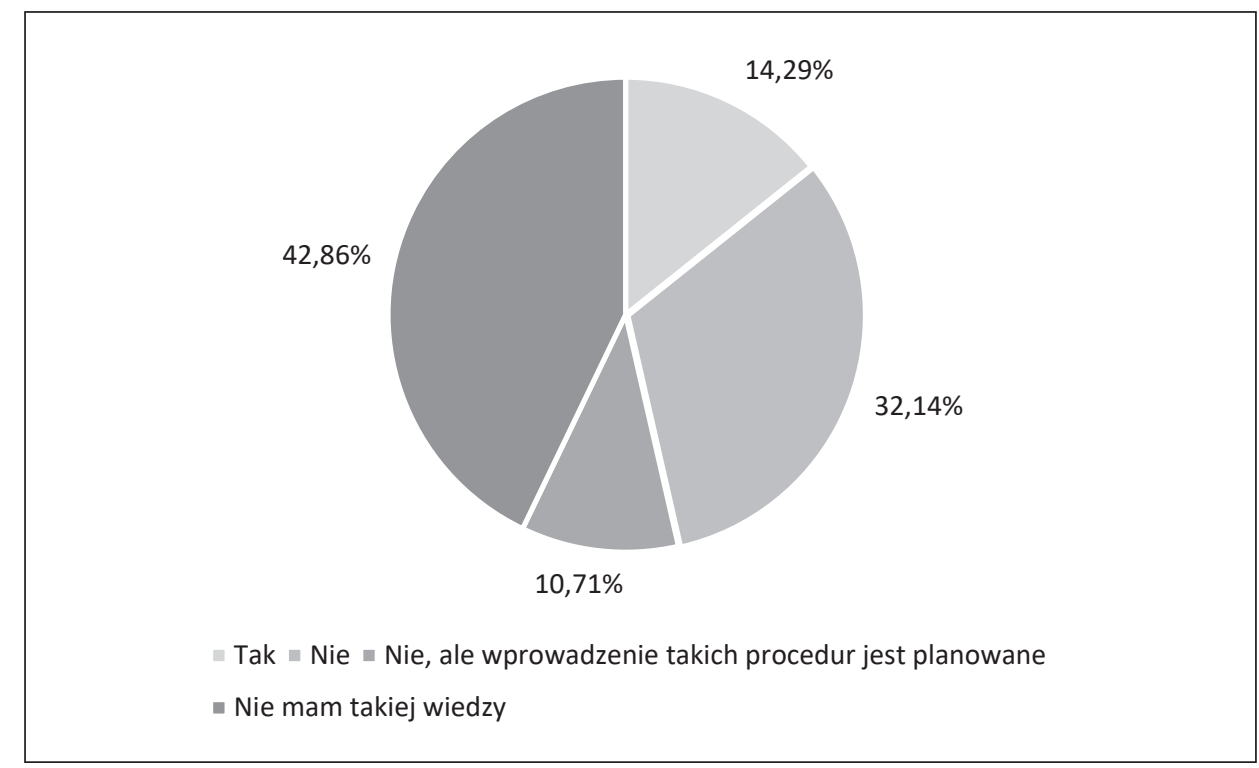

Źródło: Opracowanie własne 
Rycina 8. Wpływ rozwoju regulacji rozszerzających odpowiedzialność karną skarbową spółek oraz osób zarządzających przedsiębiorstwem na powstanie trudności związanych z zatrudnianiem osób na konkretne stanowiska

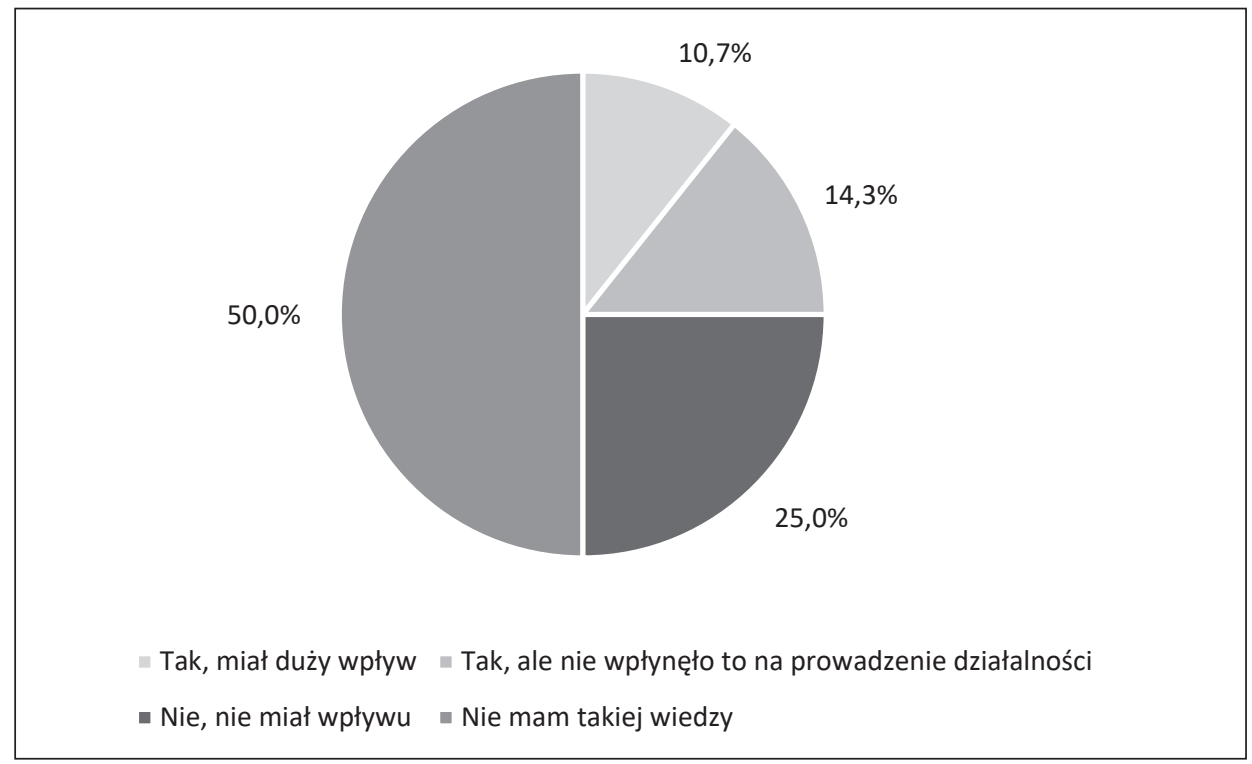

Źródło: Opracowanie własne

\section{Zakończenie}

Żyjemy w bardzo skomplikowanym otoczeniu, czego naturalną konsekwencją jest zmiana przepisów podatkowych i dostosowywanie ich do coraz to nowych wymogów i wyzwań. Jednak skala zmienności przepisów urosła do takich rozmiarów, że w istotny sposób utrudnia funkcjonowanie i rozwój podmiotów gospodarczych. W związku z tym wzrosło też znacznie ryzyko prowadzenia działalności. Podejmowanie decyzji zarządczych i finansowych poprzedzać musi dogłębna analiza obowiązujących norm prawnych w obawie wysokich sankcji. Wprowadzone rozwiązania przysparzają podatnikom wielu problemów natury praktycznej oraz wiążą się z większą biurokracją i wieloma dodatkowymi czynnościami.

Przedsiębiorcy ocenili polski system podatkowy jako mało przyjazny dla podatnika. Związane jest to ze znaczną zmiennością przepisów, zbyt krótkim czasem od momentu uchwalenia ustaw do ich wprowadzenia w życie oraz brakiem spójności pomiędzy poszczególnymi aktami prawnymi. Ich zdaniem niekorzystnie wypada również dostępność do indywidualnej interpretacji przepisów. Najwięcej trudności sprawiały przedsiębiorcom kwestie związane $\mathrm{z}$ raportowaniem schematów podatkowych, ceny transferowe oraz zbyt duża liczba obligatoryjnych sprawozdań przekazywanych organom skarbowym. Prowadzenie działalności gospodarczej dodatkowo utrudniała odmienna interpretacja tych samych przepisów podatkowych. Wyniki przeprowadzonego badania wskazują na dużą złożoność i małą stabilność polskiego systemu podatkowego.

Niska ocena przedsiębiorców na temat systemu podatkowego znajduje swoje odzwierciedlenie w międzynarodowym rankingu konkurencyjności systemów podatkowych 
krajów OECD, opracowanym przez fundację Tax Company (Bunn, Asen, 2020). Polski system podatkowy zajął w rankingu 34 miejsce na 36 możliwych.

\section{Literatura}

\section{References}

Biznes.gov.pl. (2021, 28 marca). Konstytucja Biznesu. Pozyskano z: https://www.biznes.gov.pl/pl/ ulatwienia-dla-biznesu/konstytucja-biznesu

Bunn, D., Asen, E. (2020). International Tax Competitiveness Index 2020. Washington D.C.: Tax Foundation.

Bylicki, L. (2016). Polski system podatkowy - zagadnienia ogólne. Zeszyty Naukowe PWSZ w Płocku, Nauki Ekonomiczne, 1(23), 289-309.

Czubakowska, K., Grodzińska, A. (2013). Ocena systemu podatkowego w opinii przedsiębiorców z województwa zachodniopomorskiego. Zeszyty Naukowe Uniwersytetu Szczecińskiego, 765. Finanse, Rynki Finansowe, Ubezpieczenia, 61(2), 21-33.

Dyrektywa Rady (UE) 2018/822 z dnia 25 maja 2018 r. zmieniająca dyrektywę 2011/16/UE w zakresie obowiazkowej automatycznej wymiany informacji $w$ dziedzinie opodatkowania $w$ odniesieniu do podlegających zgłoszeniu uzgodnień transgranicznych. (2021, 3 kwietnia). Pozyskano z: https://eurlex.europa.eu/legal-content/PL/TXT/PDF/?uri=CELEX:32018L0822\&from=EN

Dzwonkowski, H. (2010). Prawo podatkowe. Warszawa: Wydawnictwo C.H. Beck.

Grant Thornton. (2021, 3 kwietnia). Barometr Prawa. Edycja 2019. Pozyskano z: https://barometrprawa. pl/wp-content/uploads/2019/02/GrantThornton_barometr_prawa_022019.pdf

Grant Thornton. (2021, 3 kwietnia). Barometr Prawa. Edycja 2020. Pozyskano z: https://grantthornton. pl/wp-content/uploads/2020/03/Barometr-prawa-RAPORT-2020-03-05-2020.pdf

Grant Thornton. (2021,3 kwietnia). Barometr Prawa. Edycja 2021. Pozyskano z: https://grantthornton.pl/ wp-content/uploads/2021/03/Barometr-prawa-2021-RAPORT-Grant-Thornton-04-03-2021-1. pdf

Komisja Europejska. (2016). Study on feasibility of alternative methods for improving and simplyfing the collection of VAT through the means of modern technologies and/or financial intermediaries. (2021, 22 lutego). Pozyskano z: https://op.europa.eu/en/publication-detail/-/publication/e0d6a4f7-9ada11e6-868c-01aa75ed71a1

Komorowski, J. (2007). System podatkowy z perspektywy reformy finansów publicznych. W: J. Ostaszewski (red.), O nowy ład podatkowy w Polsce. Warszawa: Oficyna Wydawnicza Szkoły Głównej Handlowej, 123-237.

Krajowa Administracja Skarbowa. (2020; 2021, 5 kwietnia). Informacja o działalności Krajowej Informacji Skarbowej w 2019 roku. Pozyskano z: https://www.kis.gov.pl/documents/6609173/6735367/ Informacja_o_dzialalnosci_KIS_w_2019.pdf

Krajowa Administracja Skarbowa. (2021;2021, 5 kwietnia). Informacja o działalności Krajowej Informacji Skarbowej w 2020 roku. Pozyskano z: https://dane.gov.pl/pl/dataset/665/resource/28334,informacja-o-dziaalnosci-krajowej-informacji-skarbowej-w-2020-roku/table

Mastalski, R. (2000). Prawo podatkowe. Warszawa: Wydawnictwo C.H. Beck.

Making Tax Simpler: A Government Green Paper on Tax Administration. (2015; (2021, 3 sierpnia). Wellington: New Zealand Inland Revenue. Pozyskano z: https://taxpolicy.ird.govt.nz/-/media/ project/ir/tp/publications/2015/2015-dd-mts-1-tax-administration/2015-dd-mts-1-tax-administration-pdf.pdf?modified $=20200910085628 \&$ modified $=20200910085628$

Mazurek-Chwiejczak, M. (2016). Efektywny ekonomicznie system podatkowy - w poszukiwaniu modelowych rozwiązań. Finanse, Rynki Finansowe, Ubezpieczenia, 4(82/1), 781-791. https://doi. org/10.18276/frfu.2016.4.82/1-65

Mikrut, A., Poznańska A. (2009). Strategia podatkowa przedsiębiorstwa. Zeszyty Naukowe Małopolskiej Wyższej Szkoły Ekonomicznej w Tarnowie, 2(13/2), 225-238. 
Nakonieczny, J. (2020). Sealing the Tax System in Poland. Conference Proceedings, 35th IBIMA Conference, 1-2 April 2020, Seville, Spain.

Ofiarski, Z. (2013). Ogólne prawo podatkowe. Zagadnienia materialnoprawne i proceduralne. Warszawa: LexisNexis.

Pach, J. (2017). Dylematy systemu podatkowego w Polsce. Prace Komisji Geografii Przemystu Polskiego Towarzystwa Geograficznego, 31(3), 229-243.

Pach, J. (2018). Formy i skutki niepłacenia oraz wyłudzania zwrotu podatku w Polsce na wybranych przykładach. Prace Komisji Geografii Przemystu Polskiego Towarzystwa Geograficznego, 32(2), 175-189. https://doi.org/10.24917/20801653.322.12

Podatki.gov.pl. (2019; 2021, 11 sierpnia). Podatki w Polsce. Pozyskano z: https://www.podatki.gov.pl/ abc-podatkow/podatki-w-polsce/ (2021, 11 sierpnia)

Podatki.gov.pl. (2021, 9 sierpnia). Założenia Programu Współdziałania. Pozyskano z: https://www.podatki.gov.pl/program-wspoldzialania/zalozenia-programu-wspoldzialania/

Raczkowski, K. (2016). Determinanty efektywności fiskalnej systemu podatkowego. Annales Universitatis Mariae Curie-Skłodowska, Oeconomia, 50(1), 71-80. https://doi.org/0.17951/h.2016.50.1.71

Sejm RP. Uchwalone ustawy. (2021, 3 kwietnia). Pozyskano z: http://www.sejm.gov.pl/Sejm9.nsf/agent. $\mathrm{xsp}$ ? symbol=USTAWYALL\&NrKadencji $=9 \&$ NrPosiedzenia $=27$

Stiglitz, J.E. (2004). Ekonomia sektora publicznego. Warszawa: PWN.

System stworzony od podstaw, czyli prawdziwa historia 25-lecia polskich podatków. (2014). Warszawa: EY. Szymankiewicz, M. (2019). Przymusowa podzielona płatność już za kilka dni. Rzeczpospolita, 246(11489), D1. Ustawa z dnia 29 sierpnia 1997 r. Ordynacja podatkowa. Dz.U. 2018 poz. 800, z poźn. zm.

Ustawa $z$ dnia 23 października 2018 r. o zmianie ustawy o podatku dochodowym od osób fizycznych, ustawy o podatku dochodowym od osób prawnych, ustawy - Ordynacja podatkowa oraz niektórych innych ustaw. Dz.U. 2018, poz. 2193.

Ustawa z dnia 12 kwietnia 2019 r. o zmianie ustawy o podatku od towarów i ustug oraz niektórych innych ustaw. Dz.U. 2019, poz. 1018.

Wach, K. (2005). Systemy podatkowe krajów Unii Europejskiej. Kraków: Oficyna Ekonomiczna.

Walczak, B. (2003). Systemy podatkowe: teoria i stan obecny polskiego systemu podatkowego. Szczecin: PTE.

Żyżyński, J. (2009). Podatki równowagi społeczno-ekonomicznej. Nierówności Społeczne a Wzrost Gospodarczy, 14, 55-70

Joanna Nakonieczny, dr nauk ekonomicznych, adiunkt badawczo-dydaktyczny Politechniki Rzeszowskiej, Wydziału Zarządzania, Zakładu Finansów, Bankowości i Rachunkowości. Wieloletni specjalista ds. rachunkowości finansowej. Członek Rady Nadzorczej spółki kapitałowej. Główny obszar jej badań obejmuje zagadnienia z zakresu rachunkowości finansowo-podatkowej, rachunkowości zarządczej i efektywności kapitału intelektualnego.

Joanna Nakonieczny, PhD in Economics, research and teaching assistant professor at Rzeszów University of Technology, Faculty of Management, Department of Finance, Banking and Accounting. Long-term specialist in financial accounting. Member of the Supervisory Board of a capital company. The main area of research covers issues in the field of financial and tax accounting, management accounting and the effectiveness of intellectual capital.

ORCID: https://orcid.org/0000-0002-5069-2514

\section{Adres/Address:}

Politechnika Rzeszowska im. I. Łukasiewicza

Wydział Zarządzania

Zakład Finansów, Bankowości i Rachunkowości

ul. Akademicka 2, Arcus, p. 320.

35-084 Rzeszów, Poland

e-mail: j.nakonieczny@prz.edu.pl 
Renata Nesterowicz, dr nauk ekonomicznych, adiunkt dydaktyczny Uniwersytetu Rzeszowskiego, Kolegium Nauk Społecznych, Instytutu Ekonomii i Finansów w Katedrze Finansów i Rachunkowości. Autorka licznych publikacji z zakresu finansów i rachunkowości. Jej zainteresowania naukowe to ocena wyników i dokonań małych i średnich przedsiębiorstw w Polsce.

Renata Nesterowicz, PhD in Economics, assistant professor at the University of Rzeszów, College of Social Sciences, Institute of Economics and Finance at the Department of Finance and Accounting. Author of numerous publications in the field of finance and accounting. Scientific interests include the evaluation of the results and achievements of small and medium-sized enterprises in Poland.

ORCID: https://orcid.org/0000-0002-0254-9633

\section{Adres/Address:}

Uniwersytet Rzeszowski

Instytut Ekonomii i Finansów

Katedra Finansów i Rachunkowości

ul. Ćwiklińskiej 2a, p. 201

35-959 Rzeszów, Poland

e-mail: rbnester@onet.eu 